\title{
Entre mitología, filosofía y ciencia: lo apeiron y la imagen de Anaximandro transmitida por la doxografía
}

\section{Between Mythology, Philosophy, and Science: Apeiron and Anaximander's Image Handed Down by Doxography}

\author{
Marco Antonio López \\ Universidad Nacional Autónoma de MÉXICO
}

\section{Resumen:}

El texto revisa el supuesto básico desde el cual parte la interpretación más difundida de Anaximandro en nuestros días. Se señalan algunas limitaciones de dicha lectura y se subraya la necesidad crítica de encontrar alternativas, resaltando especialmente las interpretaciones que asumen el vínculo entre mitología y filosofía en los albores del pensamiento griego. La interpretación de apeiron, en función de su significado mítico-poético griego, proporciona una visión distinta de la imagen usual de Anaximandro.

Palabras clave: presocráticos, Anaximandro, filosofía griega, mitología griega

\section{Abstract:}

The text reviews the basic assumption of Anaximander's current and most widespread interpretation. It points out some limitations of this reading and underlines the critical need to find alternatives, highlighting especially the interpretations that assume the link between mythology and philosophy at the dawn of Greek thought. The interpretation of apeiron, based on its Greek mythical-poetic meaning, provides a different view of Anaximander's usual image.

Keywords: presocratics, Anaximander, Greek philosophy, Greek mythology 


\section{I}

En los dísticos finales del Himno Homérico a Deméter aparece la primera referencia literaria a los llamados Misterios de Eleusis, festividad religiosa antigua -clausurada en 392 d. C.—, cuya velada significación puede atisbarse en los siguientes versos traducidos por Alberto Bernabé:

Y ella se puso en marcha y enseñó a los reyes que dictan sentencias [...] misterios venerables que no es posible en modo alguno transgredir, ni averiguar, ni divulgar

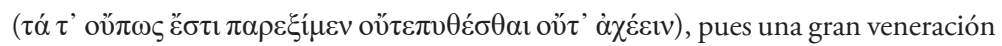
por las diosas contiene la voz. ¡Feliz aquel de entre los hombres que sobre la tierra viven que llegó a contemplarlos! Mas el no iniciado en los ritos, el que de ellos no participa, nunca tendrá un destino semejante, al menos una vez muerto bajo la sombría tiniebla. (Himnos homéricos, II, 473)

Las divinidades invocadas en el himno son Deméter y su hija Perséfone, reina del Inframundo. Según el poeta —quizá Homero, quizá un rapsodo homérico—,

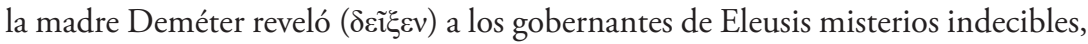
relacionados con la vida y con la muerte. Quienes han presenciado (ö $\pi \omega \pi \varepsilon v)$ lo sucedido en el culto, serán agraciados una vez muertos; quienes no han sido ini-

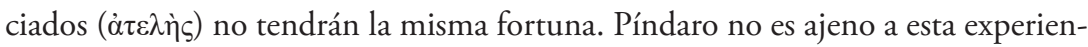
cia cuando, en un pasaje con evidentes tintes eleusinos, exclama entusiasmado: "FFeliz el que, después de haberlos visto, desciende a la tierra; feliz el que conoce el fin de la vida, y conoce el comienzo que otorgan los dioses [Zeus]" (Odas y fragmentos, frag. 137). ${ }^{1}$ Lo contemplado (i்óv) en los misterios, según el aedo, dota al iniciado de un conocimiento (oĩ $\delta \varepsilon$, oĩ $\delta \varepsilon v$ ), de una visión especial en torno a la vida, a la muerte y a su origen (⿳亠口冋 $\rho \alpha \dot{\alpha} v)$.

Además del Himno Homérico y el fragmento pindárico, las fuentes antiguas registran otra serie de testimonios igualmente relacionados con los mitos de Deméter y Perséfone: el rapto de Core, la búsqueda de su madre, la boda con Hades, el retorno de la tierra fértil, entre otras narraciones que configuran el "marco mitológico de los Misterios eleusinos" (Kerényi, 2004: 53). Marco trazado con los mitos contenidos en las fuentes grecorromanas, mano a mano con los vestigios arqueológicos llegados a nuestros días. Ahora bien, a finales de los años ochenta, el filósofo-filólogo Giorgio Colli emprende un análisis poco común del presocrá-

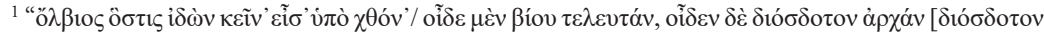

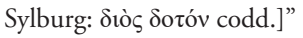


tico Anaximandro. Sin dejar de lado posibles influencias órficas, el italiano insinúa en un par de ocasiones un vínculo entre el sentido de los fragmentos del milesio y la experiencia religiosa al interior de la festividad eleusina (Colli, 2008: 301, 304). Para Colli, los profundos enlaces entre la religiosidad griega y los primeros filósofos no se limitan al par de menciones sobre Anaximandro, todos los sabios griegos más antiguos muestran la impronta de la religión helénica bajo los míticos rostros de Apolo y Dioniso (Aragay, 1993: 111). ${ }^{2}$ Pero a diferencia de la mayoría de presocráticos estudiados por Colli, éste parece notar en Anaximandro una mayor carga eleusina. En su momento, Nietzsche mismo resaltó la "idea mitológica” (Mythologischen Idee) inmersa en la sentencia del sabio milesio (Nietzsche, 2003: 48), opinión probablemente asumida e interpretada a su modo por Colli al formular, en este caso particular, "una afinidad entre el conocimiento supremo que se alcanza en la celebración mistérica de Eleusis y el que se atribuye a Anaximandro" (Colli, 2008: 304). Aquello contemplado y visto por los iniciados en Eleusis, se transluce en la "idea mitológica" infiltrada en los fragmentos del sabio milesio.

A nosotros, hombres y mujeres del siglo XXI, podrían sonarnos extrañas las afirmaciones de Colli cuando defiende el parentesco entre Anaximandro y la fiesta eleusina. ¿No se supone que la gran aportación de Anaximandro fue separarse de una vez por todas de sus esquemas mitológicos tradicionales?, ¿no se supone que Anaximandro y los milesios dieron ese gran paso llamado coloquialmente "del mito a logos"? Para quienes nos dedicamos al quehacer filosófico —en especial quienes están iniciando sus estudios en esta rama de las Humanidades - es frecuente escuchar y aceptar sin mayor inconveniente aseveraciones cercanas o derivadas, por ejemplo, de la añeja aunque para muchos vigente tesis de John Burnet: "Los filósofos jonios - con Anaximandro y los milesios a la cabeza — han abierto el camino que la ciencia después sólo ha intentado seguir [...] Sería enteramente falso buscar los orígenes de la ciencia jónica en una concepción mítica cualquiera" (Burnet, 1994: 5). Observar una "idea mitológica" o un "marco mitológico" en los fragmentos de Anaximandro pareciera contrariar esta difundida imagen aceptada por Burnet y la línea de investigación a la cual pertenece. ${ }^{3}$

\footnotetext{
2 En otra obra, sugiere Colli: "remite a la experiencia de la que el nombre de Eleusis es un recuerdo, y que fue la matriz de donde surgieron estos sabios" (Colli, 1996: 214).

${ }^{3}$ Como bien lo resume Jaap Mansfeld, en los últimos siglos podemos ubicar dos tendencias interpretativas del fragmento DK B1 de Anaximandro: la secular y la mística (Mansfeld, 2010: 11). En el siglo XX, la lectura secular naturalista comienza con el norteaméricano Arthur Heidel (1908) y es continuada por el escocés Burnet en la cuarta edición de su obra (1930), cambiando este último su inicial intepretación mística de 1892 (Burnet, 1994: 28). De acuerdo con Mansfeld, en la segunda mitad del siglo XX aparece otra vertiente secular representada por J.P. Vernant y la Escuela de París,
} 
En los siguientes párrafos, mi intención inicial será perfilar algunas notas que permitan localizar de dónde proviene la imagen de Anaximandro más conocida en la actualidad y, con base en tal ubicación general, señalar de qué modo esa imagen presupone una definición específica de la actividad filosófica. Formularé con otros términos el asunto: seguimos aceptando mecánicamente que los primeros filósofos abandonaron toda la marańa de creencias míticas para responder racionalmente a la pregunta por el origen de todas las cosas; que en lugar de apelar a los mitos tradicionales, los milesios olvidaron a sus divinidades, se lanzaron a la explicación físico-natural de los fenómenos y, gracias a ese "milagro griego", el entendimiento humano ha progresado en su conocimiento científico de la naturaleza. Si, como digo, continuamos suscribiendo esa imagen coreada y reforzada por siglos, entonces será difícil abrir la mirada ante la efigie de Anaximandro sugerida por las afirmaciones del nietzscheano Colli, será engorroso admitir la estampa de un marco mitológico en el milesio. Reconociendo las limitaciones de la imagen dominante, en un segundo momento del texto, estaremos en disposición de observar algunos rastros de esa idea eleusina en Anaximandro.

\section{II}

La interpretación usual de Anaximandro proviene esencialmente de la tradición peripatética. La Física y la Metafísica aristotélicas son las fuentes primarias defensoras de los "físicos" de Mileto, los primeros pensadores racionales. El caso de Anaximandro es paradigmático. Buena parte de la tradición doxográfica antigua mantiene por centurias la imagen del Anaximandro físico, abanderado de métodos racionales libertadores de la mitología tradicional. La imagen peripatética ha sido tan poderosa que, en nuestra época, el influyente estudio realizado en los ańos sesenta por Charles Kahn, Anaximander and the Origins of Greek Cosmology, reproduce y amplifica, con las modernas herramientas de investigación, una hipótesis

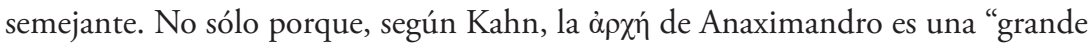
e inexpugnable masa" o porque el milesio posea una "aproximación puramente geométrica a la astronomía” o una "doctrina específicamente matemática” (Kahn,

donde Anaximandro es interpretado no de manera naturalisata sino en clave política. La lectura secular domina el siglo XX y lo que va del XXI. Por su parte, la interpretación mística impera en el siglo XIX, y en ella destacan pensadores como Schleiermacher, Creuzer, Rohde, Nietzsche y Diels, entre muchos otros filósofos y filólogos — en su mayoría germanos — como defensores del primigenio misticismo del milesio. En siglo XX, en efecto, Colli es heredero de la lectura mística del XIX (2010). 
1994: 233, 80, 77), ${ }^{4}$ entre otras muchas referencias a su cientificidad, sino también porque, a final de cuentas, Anaximandro — esto es muy significativo- "es el precursor de la mentalidad moderna" (1994). Sus aportaciones a la ciencia griega son promotoras, en más de un sentido, del nacimiento de la ciencia moderna.

De entrada, vale la pena remarcar la continuidad entre la imagen delineada por los doxógrafos antiguos y aquella retocada para nuestra época a través de las pinceladas kahnianas. Un presupuesto clave para observar la continuidad entre ambas imágenes es la fiabilidad otorgada a los testimonios peripatéticos más tempranos. Para Kahn, son Aristóteles y Teofrasto "los únicos dos testigos cuyas voces merecen ser escuchadas"; Teofrasto, afirma en otra parte el mismo Kahn, es una fuente “absolutamente confiable” (Kahn, 1994: 11-75). La tradición doxográfica posterior a los primeros peripatéticos no parece juzgar de manera distinta los testimonios originales. Diógenes Laercio, Hipólito, Simplicio o Aecio, por lo general se basan en Aristóteles o Teofrasto para construir la imagen más difundida de Anaximandro.

A pesar de lo anterior, el retrato de los doxógrafos tardíos añade matices no del todo evidentes en Aristóteles. Nuestro conocimiento acerca de las capacidades matemáticas, geométricas y astronómicas de Anaximandro — tan encumbradas por Kahn — son más bien difusas en Aristóteles. Salvo el testimonio aparecido en $D e$ Caeolo, donde se expone el reposo de la tierra por su equidistancia con los extremos, ${ }^{5}$ nada hay en el corpus aristotelicum en torno a los conocimientos geométricos o astronómicos del milesio. Es más, según argumenta David Furley, De caelo está malinterpretando la visión de Anaximandro. En consecuencia, los testimonios relativos a la estabilidad de la tierra no conllevan a un saber astronómico específico. ${ }^{6}$ Pero después de Aristóteles, claramente en Laercio, Simplicio y ante todo en la fuente conocida bajo el nombre de Aecio, quienes probablemente hagan referencia a la obra perdida de Teofrasto, Opiniones de los físicos, se describen mejor las actividades geométricas y astronómicas atribuidas al milesio — actividades, repito, nada evidentes en Aristóteles-.

\footnotetext{
${ }^{4}$ He privilegiado las traducciones castellanas de los textos. Las traducciones de las citas en francés e inglés son mías.

${ }^{5}$ Aristóteles, Acerca del cielo, 295b.

${ }^{6}$ El pasaje de Aristóteles es analizado detenidamente por David Furley, quien problematiza las afirmaciones del estagirita sobre la doctrina del milesio. Según Furley, existe una confusión en los testimonios. Aristóteles parece atribuirle al milesio una especie de "teoría de la atracción" al sostener que la tierra se mantiene en reposo en el centro del cosmos (Furley, 1987: 26). Probablemente lo que quiso decir el milesio fue que la tierra plana está equilibrada en sus puntos más extremos; es decir, no se inclina cual balanza de un lado al otro, se mantiene estable y, por ello, mantiene su centro.
} 
A grandes rasgos, las fuentes doxográficas helenísticas aderezan la imagen del "físico" Anaximandro al atribuirle los conocimientos astronómicos suficientes para dar cuenta de una compleja visión del universo; lo hace Laercio $^{7}$ seguido por el léxico Suda, así como una serie de testimonios de Aecio (Mansfeld y Runia, 2009: II, 20, 1; II, 21 , 1; II, 25, 1; II, 29, 1; III, 3, I), presentándolo como el creador de una intrincada cosmología, estableciendo con números fijos las distancias entre la tierra y los planetas. Anaximandro, además de físico, según nos muestran dichas fuentes, debía gozar de considerable erudición geométrica y astronómica para dar cuenta de semejantes distancias.

Según la misma línea doxográfica, Anaximandro fue capaz de manipular principios de aquéllas ciencias, debido a su conocimiento de la geometría oriental enseñada a él por su maestro Tales de Mileto: "Tales, tras viajar a Egipto, fue el primero en introducir esta ciencia — la geometría- a Grecia; él mismo descubrió muchas cosas e indicó los principios de muchas otras para sus sucesores”. Así lo expone Proclo en su Comentario a los Elementos de Euclides, ${ }^{8}$ quien resume las opiniones de otros autores, como Josefo, Plutarco y Jámblico acerca del viaje de Tales a Egipto, ${ }^{9}$ además de pormenorizar sus aportaciones a la geometría. El famoso teorema nombrado "de Tales", la división de la circunferencia en $360^{\circ}$, entre otras conocidas demostraciones, son plenamente asumidas por Proclo, y automáticamente adjudicadas a Anaximandro.

Para el caso de la astronomía, se mantiene el mismo esquema oriental con diferencias sutiles. Laercio, ${ }^{10}$ la Suda y Eusebio, ${ }^{11}$ atribuyen a Anaximandro la invención o utilización del llamado gnomon, un instrumento usado por los astrónomos antiguos para señalar las horas del día y otros fenómenos celestes. Heródoto piensa que dicho aparato y muchos conocimientos astronómicos llegan a tierras griegas a través de Babilonia, cuna de astrónomos, ${ }^{12}$ aunque autores contemporáneos sugieren factible el origen egipcio del instrumento (Couprie, 2002: 180). ${ }^{13}$ Sea egipcio o babilónico, lo subrayable del gnomon es la obtención de conocimientos

7 Diógenes Laercio, Vidas y opiniones de los filósofos ilustres, II, 20, 1; II, 21, 1; II, 25, 1; II, 29, 1; III, 3, I.

${ }^{8}$ Proclo, Comentario a los Elementos de Euclides (A commentary on the first book of Euclid's Elements), 64, 17-65, 11.

${ }^{9}$ Plutarco, Isis y Osiris, 364d; Jámblico, Vida Platónica, II, 12; Flavio Josefo, Contra Apión, I, 2.

${ }^{10}$ D. Laercio, Vidas..., II, 1.

${ }^{11}$ Eusebio, Prep. Ev., X, 14, 11.

${ }^{12}$ Heródoto, Historia, II, 109.

${ }^{13}$ Véase también Naddaf (2002: 52, nota 159). El origen egipcio del gnomon no está plenamente aceptado por los especialistas. De los dos artículos citados, Naddaf parece estar un poco más convencido que Couprie sobre la procedencia egipcia del instumento. 
astronómicos desde Oriente, por vía directa o por Tales, construyendo Anaximandro una compleja cosmología con ordenaciones y distancias entre los astros.

Es posible ampliar esta imagen transmitida por Laercio, Eusebio o Proclo al vincularla con las afirmaciones de Eratóstenes y Estrabón sobre las aportaciones de Anaximandro a la geografía antigua. Estrabón, ${ }^{14}$ aparentemente siguiendo a Eratóstenes, sostiene que Anaximandro fue el primero en dibujar la circunferencia de la tierra, el primero en trazar un plano geográfico, $\gamma \varepsilon \omega \gamma \rho \alpha \varphi \iota \kappa o ̀ v ~ \pi i ́ v \alpha \kappa \alpha$, del circui-

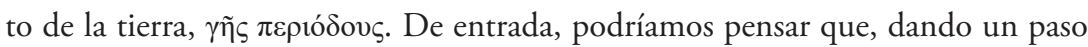
más allá de su maestro Tales, su discípulo Anaximandro se vale de conocimientos geométricos y astronómicos para extender la sapiencia milesia hacia la geografía. Sustentado en observaciones de fenómenos celestes, Anaximandro utilizaría entonces un gnomon de manufactura oriental, midiendo y ordenando dichos fenómenos, para finalmente aplicar teoremas geométricos en la configuración de ángulos y latitudes geográficas. No parece descabellado formular algo así considerando que para los geógrafos antiguos el gnomon les sirve precisamente para eso. Estrabón describe cómo el artefacto se utiliza como horologium, un reloj para marcar las horas o también como calendario, determinando estaciones, solsticios, equinoccios, la oblicuidad de la eclíptica y, si el gnomon está orientado adecuadamente, el emplazamiento del ecuador celeste permite localizar latitudes terráqueas (Aujac, 1984: 36). Anaximandro, según dicho enfoque, emplearía todos sus saberes geométricos y astronómicos a favor de la geografía, reforzando la imagen del científico promotor de la racionalidad milesia.

Como se advierte en el sucinto recuento anterior, los doxógrafos antiguos, en particular helenísticos, son quienes configuran la imagen del Anaximandro poseedor de amplios conocimientos geométrico-astronómicos y su posible aplicación geográfica. No deja de ser problemático el papel desempeñado por los peripatéticos tempranos en la fabricación de esta imagen. Aristóteles no es nada claro al respecto y, en todo caso, sería en la supuesta fiabilidad de Teofrasto en quien podrían justificarse ciertas atribuciones de corte científico. Una fiabilidad, cabe añadir, desde hace tiempo muy cuestionada por Harold Cherniss (1991), J. B. McDiarmid (1953: 192-237), Michael Stokes (1971: 28), entre otros estudiosos contemporáneos. ${ }^{15}$

El grueso de las investigaciones actuales, basándose en las fuentes helenísticas, perpetúan los conocimientos geométricos y astronómicos de Anaximandro. En esto, la doxografía antigua y contemporánea, por así denominarle, se muestran próximas. Sin embargo, los intérpretes contemporáneos buscan determinar algo

${ }^{14}$ Estrabón, Geografia, I, 7.

${ }^{15} \mathrm{El}$ tema es objeto de debate. Al respecto, véase la opinión de Guthrie (1970: 239). 
sin duda desconocido por los antiguos doxógrafos. En efecto, para Kahn y quienes le siguen en este punto, "Anaximandro es el precursor de la mentalidad moderna". A diferencia de los antiguos, la insistencia en el slogan por parte de Kahn pareciera mostrar la necesidad de justificar o fundamentar el paradigma físico-matemático de la ciencia moderna en el carácter geométrico-astronómico de Anaximandro y los milesios. Serían precisamente las formulaciones científicas, también llamadas "proto-científicas", la piedra de toque de toda la cosmología racional milesia. Dicho brevemente, para las lecturas afines a las de Kahn, la cosmología mostraría los aspectos proto-científicos de Anaximandro, su metodología geométrico-astronómica se mostraría en absoluta consonancia con la racionalidad moderna.

Frente al panorama anterior me parece importante preguntar si esta imagen contemporánea de Anaximandro responde a una visión predeterminada de su quehacer. Si acaso el Anaximandro físico, geómetra, astrónomo, y podemos añadir geógrafo, "precursor de la mentalidad moderna", es un reflejo de intereses bien específicos. El cuestionamiento no es gratuito, se justifica cuando atendemos algunos datos aportados por la historiografía clásica. Los datos, en sí mismos, podrían decirnos poco. Articulados en función del paralelismo entre Anaximandro y el pensamiento moderno, por el contrario, los datos pueden iluminar presupuestos básicos a partir de los cuales se erige la imagen dominante del físico y científico Anaximandro.

En franco desacuerdo con la tesis de Kahn, David Dicks muestra la inoperatividad histórica de la interpretación kahniana. Para mi propósito, vale traer a colación las opiniones de Dicks en relación con el gnomon: "Observaciones de la sombra de un gnomon sólo pueden dar indicaciones muy burdas de la hora del día: únicamente si el gnomon está ubicado de manera tal que su eje sea paralelo al eje de la tierra, es decir, sólo si se conoce la latitud del lugar; y el concepto de latitud necesariamente presupone el conocimiento de la tierra esférica en medio de la esfera celeste" (Dicks, 1966: 29).

Siguiendo el clásico libro de Dicks, Early Greek Astronomy to Aristotle, la concepción del globo terráqueo probablemente aparece en el siglo $\mathrm{V}$ a. C., durante el pitagorismo itálico de la época de Ecpanto de Siracusa y Arquitas de Tarento, el amigo de Platón (Dicks, 1970: 62-76). La hipótesis acerca de la formulación pitagórica de la tierra esférica se basa en los comentarios generales de Aristóteles en $D e$ Caelo cuando éste describe el supuesto arreglo astral realizado por los pitagóricos y, por ello mismo, según el propio Dicks, es dudoso adjudicarles la idea (Aristóteles, 1996: 285b, 25). Incluso la autoría puede atribuírsele a Parménides, cuando habla sobre la esfericidad del cosmos (Kirk, Raven y Schofield, 1977: "Parménides", DK B1, B8, B10), no de la tierra, pero aparentemente para Anaxágoras (Kirk et al., 1977: "Anaxágoras": DK A87, A88), Diógenes de Apolonia (Kirk et al., 1977: 
“Diógenes de Apolonia", DK A1), Leucipo (Kirk et al., 1977: "Los atomistas", DK A26) y Demócrito (Kirk et al., 1977: "Los atomistas", DK B15), inmediatamente posteriores a Parménides, la tierra posee forma discoidal. ${ }^{16}$ Según Dicks, las referencias más nítidas en torno a la esfericidad aparecen con Platón en Fedón ${ }^{17}$ y en la cosmología mítica del Timeo. ${ }^{18}$ Para ser más precisos, el primero en argumentar acerca de la esfericidad de la tierra es Aristóteles, ${ }^{19}$ mediado por las notables contribuciones astronómicas de Eudoxo, quien desarrolló una teoría astronómica con improntas geométricas: la esfera celeste, la terrestre, las rotaciones planetarias y sus esferas concéntricas inclinadas (Dicks, 1970: 153). Esta última teoría, amalgamada con la geometría euclidiana en los trabajos de Aristarco, Arquímedes y Apolonio, afianza la geometrización de la astronomía griega en la época helenística. Todo ello, posterior a Anaximandro en varios siglos.

El problema se hace más acentuado si consideramos que una de las aportaciones capitales de los griegos a la astronomía como tal es precisamente la postulación de un cosmos y una tierra esférica y, con ello, la paulatina geometrización de la astronomía inaugurada por Eudoxo. En su recuento histórico de la astronomía antigua, Otto Neugebauer distingue entre los presupuestos de los conocimientos astronómicos orientales y los griegos. El sistema astronómico más antiguo, sin duda el babilónico, aplica un método esencialmente aritmético para el estudio del movimiento astral. Secuencias numéricas sirven para calcular determinados fenómenos celestes, y a pesar de que su método puede indicar, por ejemplo, las fechas aproximadas de los eclipses — muy laxas_- su teoría astronómica carece del modelo esférico del cosmos y de la tierra, del desplazamiento circular de los planetas, entre otros postulados para nosotros evidentes casi a priori, pues hemos asumido por completo la teoría griega fundada en una visión geométrica del sistema planetario (Neugebauer, 1975: 348). La esfericidad de la tierra es "un concepto del cual carece absolutamente la astronomía babilónica” (1975).

Otro tanto sucede con los egipcios. Su teoría tampoco presupone la esfericidad del universo ni la geometrización realizada por los griegos (Dicks, 1970: 167). La

\footnotetext{
${ }^{16}$ Los testimonios son problemáticos, refieren a comentaristas de las obras de Anaxágoras, Diógenes de Apolonia y Leucipo, quiénes probablemente siguen la concepción de Anaximandro. En Demócrito parece distinto pues es factible que sus palabras sostengan la forma discoidal de la tierra. Véase Pédech (1976: 3) y Eggers (1980: 277). Como señalaré, investigaciones más recientes sostienen que Parménides y Anaxágoras ya poseen la noción de esfericidad terrestre.

${ }^{17}$ Platón, Fedón, 108e.

${ }^{18}$ El diálogo no lo expresa literalmente, pero se infiere con facilidad de toda la narración. Véase Pédech (1976: 39). Lo mismo detalla Dicks (1970: 96), quien tiene en cuenta no sólo el Timeo, sino el resto de la obra platónica.

${ }^{19}$ Aristóteles, Acerca del cielo, 297a8.
} 
contribución de las teorías astronómicas orientales, en especial de la babilónica, aparecen, en todo caso, aproximadamente en 150 a. C., cuando una gran cantidad de datos numéricos calculados por el sesgo aritmético de la teoría babilónica pueden ser codificados y aplicados por los griegos gracias a los métodos trigonométricos desarrollados por Hiparco. Antes de él, las matemáticas griegas eran insuficientes para resolver problemas de orden astronómico, incapaces de establecer criterios fiables para calcular las distancias entre los planetas (Neugebauer, 1975: 4). ${ }^{20}$ También es Hiparco, y no Tales, quien introduce la división babilónica del círculo en $360^{\circ}$ al utilizarla para el estudio del zodiaco (Dicks, 1959: 308).

Los métodos trigonométricos de Hiparco permiten una clasificación pormenorizada de las estrellas en un catálogo celeste, con distancias fijadas por coordenadas eclípticas - al menos las distancias del sol y de la luna-. Esto lo lleva al terreno de la geografía. Utilizando principios astronómicos, Hiparco dibuja un mapamundi con coordenadas establecidas por los conceptos de ecuador, meridiano, longitud, latitud, etcétera (Dicks, 1955: 248). ${ }^{21}$ Aquí por primera vez parecen aplicarse los conocimientos astronómicos a la geografía, la llamada geografía matemática, astronómica o científica; cuatro siglos después de Anaximandro.

Bajo la perspectiva desplegada por Dicks, Neugebauer y otros como Alexander Jones, la influencia de la astronomía oriental en Anaximandro, Tales y los primeros astrónomos griegos resulta sumamente problemática en lo concerniente al carácter geométrico-matemático y científico (Dicks, 1970: 168). ${ }^{22}$ Incluso dando por his-

${ }^{20}$ En particular véase Jones (1991: 442), donde el autor sostiene que las adaptaciones hechas por Hiparco se basaban en los resultados de las tablas babilónicas. Sus antecesores, Aristarco y Arquímedes no hacen uso de material observable, sino todo es a priori; sin embargo, tampoco Hiparco pudo dar cuenta de distancias planetarias, únicamente las del sol y de la luna. Neugebauer (1972: 248) opina que el apriorismo de esa época se debe a la intención de los astrónomos griegos por adecuarse al canon geométrico establecido por Platón y Eudoxo. La diferencia entre el modo a través del cual Hiparco adapta los datos babilónicos y la manera ptolemaica, sostiene Jones, es que el primero expone sus resultados sin ninguna demostración, mientras el Almagesto da cuenta del proceder más científicamente; el método de Ptolomeo es deductivo y orgánico (Jones, 1991: 444). Ello parece implicar que es Ptolomeo quien adapta "científicamente" la información babilónica, no Hiparco. Este último, sigue mostrando la tendencia apriorística característica de la astronomía griega más antigua.

${ }^{21}$ Como lo nota Neugebauer, Hiparco no dominaba la trigonometría esférica, sólo la plana, y utilizó otras herramientas teóricas para subsanar esa deficiencia (Neugebauer, 1972: 247). Es con Menelao ( 100 d. C.) que aparece en Grecia la trigonometría esférica. Probablemente Eratóstenes ya aplicaba criterios semejantes a los de Hiparco.

${ }^{22}$ Dicks desarrolla cinco puntos sobre la influencia babilónica en la astronomía griega anterior a Eudoxo y Aristóteles. De la misma manera, Neugebauer esclarece la diferencia entre sostener que únicamente la astronomía babilónica, por sus patrones aritméticos, se basa en pocas o ningunas observaciones pues tampoco parce hacerlo la astronomía geométrica griega de Platón, Eudoxo, Aristarco, Arquímedes e incluso la de Hiparco (Neugebauer, 1972: 250). Véase Jones (1991: 441), en donde se 
tóricamente válida la opinión de la doxografía helenística sobre el viaje de Tales a Egipto, el milesio no tendría la capacidad de interpretar la información de la matemática egipcia, pues no existía ningún corpus mínimamente ordenado sobre el tema. En sí misma, la matemática egipcia es inadecuada para cálculos astronómicos. En todo caso, si existiese tal corpus, carecemos de noticias sobre cómo un griego del siglo VI a. C. pudiese descifrar los jeroglíficos egipcios, esto sucede en el período ptolemaico (Dicks, 1959: 307-308).

El gnomon, fuese egipcio o babilónico, de poco le habría servido a Anaximandro para fines astronómicos o geográficos. Habría necesitado manipular el método trigonométrico de Hiparco para trasladar los datos orientales a su propia comprensión o, por lo menos, valiéndose de un gran ingenio, entender los principios básicos de la astronomía geométrica. Ambas cosas pecan de anacronismo. Los primeros testimonios acerca del manejo del gnomon para conocer la hora del día a través de su sombra, su uso más primario, se presentan, según Dicks, en época helenística, cuando la noción de esfericidad de la tierra y, por tanto, de latitud, ya está consumada en las teorías griegas (Dicks, 1966: 30).

\section{III}

La crítica de Dicks a ciertos aspectos fundamentales de la tesis kahniana despierta una acalorada discusión a finales de los años sesenta y principios de los setenta en una serie de réplicas y contrarréplicas dadas por uno y otro. El enfrentamiento entre Dicks y Kahn ciertamente tiene ya sus décadas, pero sigue muy presente en estudios más recientes sobre el pensamiento presocrático resultando ineludible señalarlo. Una razón de peso para comprender la permanencia de la disputa podría ser las limitaciones de los argumentos esbozados por Kahn, imposibles de reconstruir en unas cuantas líneas (Dicks, 1972: 175-177). Para mi objetivo, en cambio, es más fructífero poner en claroscuro el presupuesto básico de su interpretación. Viendo el presupuesto, podremos entender mejor el acalorado tono de la disputa, por un lado, y sus consecuencias para la visión contemporánea de Anaximandro y los milesios, a las cuales sólo aludiré de manera general tomando como muestra algunas interpretaciones actuales, representativas del problema resaltado por aquella controversia.

defiende que es en la obra de Ptolomeo en la que los resultados de la astronomía babilónica son incoporados metódica y científicamente por los griegos, y no en Hiparco, ni Eudoxo y mucho menos en Anaximandro. 
Para ir al grano, el presupuesto último de Kahn en su defensa de la cientificidad milesia apela a la indiscutible relación entre filosofía y ciencia. Cuando Dicks pone en duda las aportaciones geométrico-astronómicas de Anaximandro o de Tales, se está poniendo en tela de juicio, según Kahn, la cientificidad de los primeros filósofos. Esto le parece inaceptable. Para Kahn son descaminadas las pretensiones de Dicks pues rompen los lazos comunicantes entre filosofía antigua y ciencia moderna: "la estrecha relación con la investigación científica actual en astronomía, geometría y biología [...] el tema al discutir la primera astronomía griega no sólo es una crítica a la doxografía por dos o tres filósofos presocráticos, sino entender el carácter fundamental de la relación entre ciencia y filosofía [...] relación iniciada en Mileto" (Kahn, 1970: 116). Al llevar a cabo una apología de la cientificidad milesia, se está demostrando simultáneamente, según Kahn, la innegable raigambre científica de la filosofía griega, la cuasi identidad entre filosofía y ciencia.

Con el objeto de tener un contexto más amplio del problema subyacente a la polémica, veamos algunos ejemplos más recientes donde se pone en evidencia, desde distintos lugares, el presupuesto básico diseminado por la lectura kahniana. Criticando directamente las conclusiones de Dicks, el norteamericano Stephen White defiende la imagen de Tales como "padre fundador de la ciencia griega" (White, 2002: 15). White pone especial énfasis en los descubrimientos astronómicos imputados a Tales por la doxografía antigua, intentando justificar con ello la paternidad de la astronomía científica a ese primer pensador milesio. No es lugar para desarrollar a detalle la argumentación de White, sino para atender la identificación entre filosofía y ciencia en cuanto punto de partida de su análisis: "Llámenle filósofo o no, [Tales] merece totalmente el crédito de fundador de la astronomía griega” (2002). Así, más que pretender identificar filosofía y ciencia, en el caso de White, pareciera mejor hablar de subsunción; su necesidad por desacreditar, siguiendo a Kahn, la exégesis de Dicks, subyace en justificar la antigüedad de la ciencia astronómica griega, ubicarla codo a codo con el nacimiento de la filosofía —en sentido aristotélico—, dando pie así a la subsunción. No importa si la actividad de Tales es filosófica, lo importante, según White, es la cientificidad de su quehacer. La filosofía o supuesta filosofía de Tales queda relegada o subsumida a la cientificidad de sus descubrimientos. Lo encumbrable, repito, no es Tales "padre" de la filosofía, sino Tales "padre" de la ciencia. Anaximandro sería, pues, un fiel epígono del patriarca de la ciencia.

En la misma línea de investigación, Livio Rossetti retorna al clásico problema de los escritos presocráticos etiquetados bajo el sello "sobre la naturaleza» o Пєрì

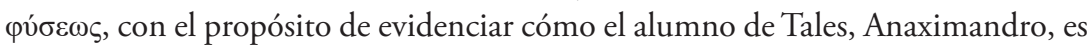
un homo unius libri, un pensador cuyo escrito único Sobre la naturaleza es una 
suerte de magna enciclopedia donde se incluyen los más admirables descubrimientos científicos articulados homogéneamente en ese tratado (Rossetti, 2015: 64). El propio Rossetti es consciente de la dificultad de "poder corroborar algo al respecto. No obstante, se impone como una eventualidad sustancialmente carente de alternativa" (2015). El artículo de Rossetti resume a su modo las pretensiones de traer a la luz la díada ciencia moderna-filosofía antigua apelando a la existencia del tratado científico tan socorrido por los pensadores modernos. Presupone, de modo semejante a Kahn, la mentalidad moderna de Anaximandro.

Algo parecido, aunque más claro en relación con el presupuesto que busco iluminar, podemos encontrarlo en el libro titulado Anaximander de Carlo Rovelli al entronar a Anaximandro como el más grande e influyente de los científicos antiguos, le llama "la primera gran revolución científica" (Rovelli, 2011: XIII). Rovelli trabaja con cierto detalle algunas cuestiones relacionadas con Anaximandro, pero su objetivo primordial es formular una definición de la ciencia basándose en los testimonios helenísticos. Baste con mencionar que de las 190 páginas del estudio, aproximadamente 130, están dedicadas a resolver la pregunta ¿qué es la ciencia? La respuesta de Rovelli pretende extender el rango de aplicación del concepto de 'ciencia' tanto como para englobar a Anaximandro y a Stephen Hawking. Bajo tal espectro, no resulta sorprendente la proximidad de las palabras de Rovelli y de Kahn: "Anaximandro se alza cual gigante del pensamiento humano, parado en las raíces más profundas de la Modernidad” (Rovelli, 2011). Hemos de añadir que en Rovelli existe un aspecto comúnmente aceptado por filósofos y científicos desde Aristóteles, decididamente explicitado en su revisitada definición de la ciencia, que además podríamos calificar como su elemento diferenciador: la actividad científica se determina a sí misma por distanciarse lo mayor posible de la visión mítico-religiosa del mundo (2011). El científico sólo se vuelve tal cuando es capaz de separar con nitidez la explicación racional-científica de los fenómenos de las "verdades absolutas" intrínsecas a las visiones mítico-religiosas. Tales de Mileto, pero en particular Anaximandro, serían los promotores de esa actitud científica crítica del poder explicativo de los mitos griegos.

En una localización genealógica de nuestro problema, Daniel Graham revive conscientemente la disputa entre Kahn y Dicks en sus textos Explaining the Cosmos: the Ionian tradition of Scientific Philosophy y Science Before Socrates. Particularmente la segunda obra entra en el problema del saber astronómico de los primeros filósofos, entronizando las figuras de Parménides y Anaxágoras en cuanto paladines de la astronomía griega y de la ciencia en general (Graham, 2013: 8). Los dos libros de Graham pueden leerse en función de una misma intención: justificar la "filosofía científica" (scientific philosophy) de los jonios. Para el caso de Anaximandro, 
Graham sigue explícitamente a Kahn en varios momentos y cuestiones (Graham, 2006: 4, nota 9, 38), exponiendo diez características por las cuales se puede hablar de un "proyecto científico" sistemáticamente elaborado por Anaximandro (Graham, 2006: 10). Graham también observa en ese proyecto milesio el primero de una "sucesión histórica ininterrumpida de teorías físicas desde los jonios al presente [...] la filosofía jonia es una extraordinaria anticipación de la ciencia moderna [...] Occidente tenía una visión científica del mundo antes de ser llamada ciencia” (Graham, 2006: 18-19). Antes de llamarse ciencia, repito la frase, la ciencia se llamaba "filosofía científica". Para Graham, en resumen, filosofía y ciencia son prácticamente idénticas: “Que la palabra 'científico' (scienstist) se acuñe en el siglo XIX no me impide llamar científico a Isaac Newton, ni saber que Anaxágoras se hacía llamar a sí mismo un sophos me impide afirmar que éste realizaba investigaciones filosóficas y científicas. Aquí, pienso que la perspectiva anacrónica funciona perfectamente" (Graham, 2013: 35). Quizá por eso mismo Graham decida narrar en su libro esta parte inicial de la filosofía occidental "desde el punto de vista de un científico o proto-científico jonio” (Graham, 2006: 4).

IV

Con el breve recuento anterior, podemos advertir las similitudes entre los presupuestos de Kahn y los estudiosos mencionados. Todos buscan unificar, casi intercambiar, la actividad filosófica y la científica. La propuesta de Graham, sin embargo, trae a la luz la dimensión completa de dicho presupuesto al denominar "pesimistas" a las posiciones críticas mostradas por Dicks y otros autores afines a éste —al menos en este punto, según Graham—, como Lloyd o Vlastos (Graham, 2006: 10). ¿Por qué llamarles pesimistas? El apelativo dice bastante y la respuesta esclarece aún más el presupuesto básico compartido con Kahn: si criticamos la cientificidad de los presocráticos, cortamos el vínculo entre filosofía y ciencia. Siguiendo a Graham, observar a los presocráticos desde un horizonte distinto al científico se enmarca en una cuestión de mayor impacto: la puesta en duda del método científico como medio para llegar a certezas y verdades sólidas sobre el mundo. En efecto, las críticas emprendidas hace tiempo por diversos frentes teóricos — constructivismo, instrumentalismo, posmodernismo — obligan a Graham a realizar una apología del método científico como único camino válido para llegar a certezas que justifiquen el real y evidente progreso de la ciencia. Con palabras del propio autor, si se hace caso a las críticas: "parece no haber modo de validar a la ciencia como una actividad que se muestra especialmente efectiva en 
resolver los secretos del mundo. Es más, se vuelve dudoso si la ciencia puede arribar a verdades sobre el mundo" (Graham, 2013: 20-21). Criticar el avance de la ciencia y su método, sería, para tal enfoque, tomar una postura "pesimista" del conocimiento humano, abriéndole la puerta a visones "irracionales"; abriéndole la puerta a una vida sin certezas, sin aplaudir el progreso de la ciencia moderna y la tecnología contemporánea como el logro cultural más "positivo" de los seres humanos.

Para Graham, según entiendo, la filosofía científica presocrática resulta crucial para demostrar históricamente a sus críticos que la ciencia efectivamente progresa y alcanza verdades. Tras bambalinas, la exégesis de fuentes clásicas, a la par del erudito manejo historiográfico en torno a la astronomía o geometría presocráticas, se dirige al objetivo más alto de salvaguardar el nombre de la ciencia, ampliándola cronológicamente lo mayor posible; incluso si ello implica la consciente utilización del anacronismo. La definición de la ciencia puede ser tan limitada — así en Rovelli- que simplemente se circunscriba a marcar distancia de las visiones míticoreligiosas, debido al estudio racional de la naturaleza, como supuestamente fue realizado por los primeros físicos de Mileto. A los ojos de Kahn o Graham, el minucioso análisis de Dicks pareciera no darse cuenta del terrible dańo causado por sus conclusiones, pues los argumentos de este último demuestran la dificultad para sostener sin obstáculos la cientificidad de Anaximandro. Las pruebas aportadas por Dicks, cabe ańadir, obviamente no cancelan por completo la posibilidad de perpetuar la imagen moderna de Anaximandro. Precisamente a eso se han dedicado otros especialistas posteriores a la polémica, aportando nuevos datos o analizando los ya conocidos a partir de enfoques distintos (Hahn, 2001). Pero, en cualquier caso, las investigaciones de Dicks esparcen una fuerte duda sobre el quehacer científico de Anaximandro. No es tan fácil asegurar, sin asomo de duda, que los milesios fueron los primeros pensadores racionales y científicos.

Tan sólo concentrándonos en los trabajos aquí mencionados de Dicks o Neugebauer viene naturalmente la necesidad de cuestionar el alcance analítico e intereses primordiales de quienes sostienen la identidad o fuerte intimidad entre ciencia y filosofía en los presocráticos iniciales. Pareciera, pues, que la intención de observar en Anaximandro al adalid de la ciencia o proto-ciencia helénica se (auto) justifica por el horizonte teórico de cada investigador. Si Kahn y quienes le siguen defienden la unión ciencia-filosofía en Anaximandro es porque, para ellos, es ahí donde se juegan aspectos fundamentales de la ciencia occidental. Parece interesarles sustantivamente la viabilidad de la ciencia moderna como paradigma explicativo en nuestro mundo actual y, en la apología de tal viabilidad, los presocráticos guardan una significación histórica que viene en auxilio de dichos intereses. 
Presuponer la íntima relación entre ciencia-filosofía y sus repercusiones para comprender el alcance de la ciencia moderna, sin duda posee valor en sí misma, de considerable importancia para ese campo de estudio particular. El tema que intento destacar, en cambio, no es si ese presupuesto es válido o no, sino situarlo en cuanto herramienta teórica básica para argumentar lo que se desea argumentar, idea que resulta clara metodológicamente hablando, pero que por momentos es opacada al pensar — no sin cierta obcecación — la existencia de un único modelo explicativo o una sola perspectiva de aproximación: la metodología científico-racional cual vía exclusiva y "seria" para aproximarnos a la realidad.

El tema nos llevaría hacia otros ámbitos de estudio humanístico — gnoseología, filosofía de la ciencia, historia de la ciencia, etcétera-, el cual no es menester profundizar en las líneas restantes. Más próximo a mi objetivo inicial, en cambio, es subrayar el papel determinante de las filiaciones teóricas de cada investigador al condicionar desde tal o cual perspectiva las cualidades filosóficas de los primeros presocráticos. Si el interés descansa en establecer el nexo entre esos primeros filósofos y las discusiones contemporáneas acerca de la ciencia moderna, dicho nexo será seńalado por el investigador y le servirá para concluir lo correspondiente. Cuando dirijamos nuestras miradas hacia el punto histórico donde, según Aristóteles, comienza la filosofía, encontraremos — de facto o potencialmente- las mismas características científicas ya prestablecidas (López Espinoza, 2019).

\section{V}

El desarrollo de los apartados anteriores deriva, entre otras cuestiones, en la necesidad crítica de formular hipótesis diferentes, cuyo horizonte tome distancia de los presupuestos y criterios analíticos tan difundidos hoy en día por Kahn y quienes observan en Anaximandro al proto-científico "precursor de la mentalidad moderna". Primeramente, porque la elección y concatenación de los datos suministrados por los doxógrafos antiguos, o por otras disciplinas humanísticas dedicadas actualmente a los Estudios Clásicos — historiografía, antropología, epigrafía, etcétera—, son interpretados en función de los intereses particulares del analista; porque esa misma información también puede ser usada, tal como lo hace Dicks, para lo contrario: para criticar o negar la existencia de esa "mentalidad moderna" en Anaximandro. En segundo lugar, apelando a otro horizonte, en especial aquel donde la mitología sea el marco interpretativo del nacimiento de la filosofía, la ordenación y conformación de los datos aportados por la doxografía antigua y los Estudios Clásicos contemporáneos mostrarán sentidos diferentes de aquellos orígenes del filosofar, y 
en la misma línea, estaremos en disposición de comprender que la filosofía no se agota en un ejercicio metódico, sistemático y racional; ejercicio éste —retomando las palabras de Burnet_ - "que la ciencia después sólo ha intentado seguir". Los fragmentos de Anaximandro muestran otras posibilidades de análisis, posibilidades exploradas por otros helenistas desde hace tiempo.

J. P. Vernant ha seńalado la presencia de dos caminos exegéticos opuestos aplicados al estudio de los filósofos presocráticos en el siglo XX. Una es justamente la promovida por Burnet y otra representada por Francis M. Cornford. Vernant considera la propuesta de este último inversa a la de Burnet: "la física jónica no tiene nada en común con lo que nosotros denominamos ciencia”; para Cornford, continua el autor francés, "la primera filosofía se acerca más a una construcción mítica que a una teoría científica" (Vernant, 1992: 117). El propio Vernant observa la estampa mítica en los albores del pensamiento griego; sin embargo, pone más énfasis en el aspecto fundacional y social de los mitos — mitos de soberanía-, donde el carácter cosmológico se retrae ante la emergencia de las necesidades políticas secularizadas; ajenas, pues, a la religión tradicional (Vernant, 1992). Es innegable la influencia del contexto sociopolítico en la filosofía griega primigenia, tal como lo han demostrado Vernant y los helenistas de la Escuela de París. Pero me gustaría ensayar una hipótesis — tan sólo eso, sin llegar a una conclusión determinada - colindante con la trazada por Cornford, una en la cual cohabiten el marco mítico-poético y el núcleo devocional de la religiosidad helénica.

En su estudio de 1926, "Las religiones mistéricas y la filosofía presocrática”, Cornford prefigura argumentos básicos desarrollados décadas después por Colli. En aquel viejo texto, Cornford incluye a Eleusis y al orfismo cuales antecedentes del pensamiento anterior a Sócrates, sin invocar, claro está, a las esferas apolínea y dionisíaca (Cornford, 1981: 89). El compendio de Cornford busca mostrar las improntas del orfismo en la escuelas filosóficas, jónicas e itálicas, influencias de las cuales Anaximandro es heredero (1981), pero no engarza los misterios eleusinos con Anaximandro, en todo caso Eleusis le resulta el antecedente mistérico de los rituales místicos y cosmogonías órficas recuperadas por los milesios.

A diferencia de otros estudios más especializados sobre la religión eleusina, para mi propósito es importante el acercamiento hecho por Cornford, su análisis está dirigido a entresacar los rasgos fundamentales que impactan en los presocráticos. Primeramente, en contraste con las ceremonias tradicionales griegas, la fiesta mistérica: "no es un 'servicio litúrgico' que externamente se dirija hacia una deidad. Aunque comporte este aspecto, posee también el de una efectividad a él inherente, esto es, una 'gracia' interna que origina un cambio en el participante y que incide por simpatía en la vida de la Naturaleza externa”. Lejos de negar la obvia jerarquía 
ritual de las divinidades mistéricas, Cornford defiende que el sentido de esa celebración, hermanado con la devoción hacia Deméter y Perséfone, subyace en la comunión simpatética con la renovación de la vida en general, con los ciclos naturales en todas sus manifestaciones: "El renacer — continúa — es un retorno a las fuentes de la vida para de ellas obtener energía nueva" (Cornford, 1981: 92).

La inmortalidad de las divinidades mistéricas difiere de aquella distintiva de las figuras olímpicas por su mayor cercanía con los avatares y sufrimientos humanos ante la muerte: "Sólo el dios que es inmortal en el sentido de que perece y, sin embargo resucita, puede seguir siendo uno con esa vida que gira en la rueda del tiempo [...] al elevarse al nivel de una Idea (Idea), el pensamiento implícito que de aquí surge es la doctrina panteísta de la continuidad de toda vida" (Cornford, 1981: 94-95). La palingenesia experimentada por el iniciado, asumida, pues, como la "Idea" del continuo fluir de la vida, involucra una transformación de sí mismo. Una vez contemplado y sufrido lo sucedido al interior del templo eleusino, ya no se puede ser la misma persona. "Aquellos que han visto los misterios", tal cual lo cantan el citado Himno Homérico a Deméter y el propio Píndaro, se sienten agraciados, portadores de un beneficio divino tan activo que inaugura en ellos la reforma de su propia existencia. La reforma incorpora ese sentimiento de inmortalidad circular con la cual el iniciado se siente tocado no porque esté exento de morir, sino por verse inmerso en perpetuo renacimiento: "para la vida humana la «inmortalidad" significa un perpetuo renacer a esta vida terrena, y no una escapatoria de la rueda del renacer en la forma de una inmortal eternidad" (1981).

Mencionaba que para el artículo de 1926 la imagen de Anaximandro descrita por Cornford está más cerca de la mística órfica y sus respectivas cosmogonías, que de la experiencia eleusina (Mansfeld, 2010: 25). ${ }^{23} \mathrm{~A}$ pesar de ello, se pueden traer a colación algunos datos apoyando la conexión entre los fragmentos del milesio y la "Idea" expresada en el continuo renacer de la vida, en las formas mitológicas de las divinidades mistéricas eleusinas, Deméter y Perséfone. Pensemos, de entrada,

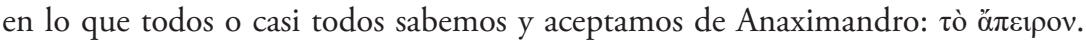
¿Cuánto tiempo la historia de la filosofía se ha roto la cabeza en su intento por apresar el significado de esa palabra en el milesio? No es lugar para emprender el trabajo de evaluar las traducciones y significaciones más familiares del término, voy a centrarme en una sola para proponer, en cuanto hipótesis, el cuadro donador de sentido mitológico de öлzıрov. Para ello es ineludible apelar a la tradición poética

${ }^{23}$ Cornford también es un exponente tardío de la lectura mística de Anaximandro imperante en el siglo XIX. 


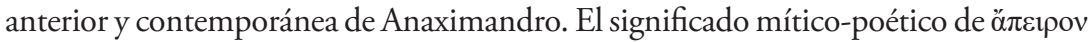
ilumina aspectos cardinales de la experiencia eleusina.

Partiendo metodológicamente de hallar la "imagen gráfica" desde la cual brota la conceptualización del lenguaje griego, el filólogo Richard B. Onians rastrea la

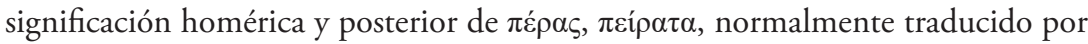
"límite", "límites", "limitación" (Onians, 1951: 324). ${ }^{24} \mathrm{El}$ análisis de Onians es prolijo en cuanto a fuentes y ejemplos — remitimos al lector al libro para los detalles lingüísticos (1951)_; por ahora, únicamente expondré algunas conclusiones suyas con ejemplos específicos relacionados con la significación mítico-poética de $\pi \varepsilon ́ \rho \alpha \varsigma$. El famoso pasaje en Ilíada: "Pues voy a los $\pi \varepsilon i ́ \rho \alpha \tau \alpha$ de la feraz Tierra a ver a Océano, progenie de los dioses, y a la madre Tetis” (Homero, 2010: XIV- 200), donde $\pi \varepsilon i ́ p \alpha \tau \alpha$ es traducido por "límites", ha de considerar que, para la Grecia Antigua, los "límites" de algo se establecen en función de, literalmente, circunscribirlo, encerrarlo trazando un círculo alrededor con una cuerda o lazo. En su significación profunda $\pi \varepsilon ́ \rho \alpha \varsigma$ es "cuerda", "cinturón”, "banda”, cuya forma anular abraza un contenido; emparentado etimológicamente, según Onians, el griego $\pi \varepsilon ́ \rho \alpha \varsigma, \pi \varepsilon \rho i ́$ con el sánscrito pari, “alrededor de” (Onians, 1951: 315). Martin West deriva el término ' $\Omega \kappa \varepsilon \alpha v o ́ \varsigma$ del acadio oginna, "anillo”, y de otra raíz sánscrita cuyo significado es "circundar" (West, 1966: 201). Así veían los griegos homéricos al dios Océano, un gran río circundando la tierra. Homero llega a cantar que es tan redondo como el escudo de Aquiles, ${ }^{25}$ y Hesíodo ańade otro tanto a la imagen de Océano circundando nueve veces la tierra. ${ }^{26} \mathrm{~A}$ través del escolio a Ilíada, ${ }^{27}$ tenemos noticia de los versos poco conocidos del poeta Euforion: ' $\Omega \kappa \varepsilon \alpha v o ́ \varsigma, \tau \tilde{\omega} \pi \tilde{\alpha} \sigma \alpha \pi \varepsilon \rho i ́ p \rho \imath \tau \varsigma$ $\dot{\varepsilon} v \delta \varepsilon ́ \delta \varepsilon \tau \alpha \imath \chi \theta \omega ́ v$, "Océano, a toda la tierra circunscribe", utilizando el vocablo

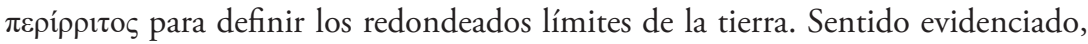
por ejemplo, en Teognis (Lirica Griega Arcaica II, 1959: 140) ${ }^{28}$ y en el poema de

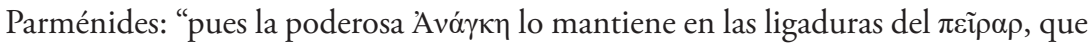

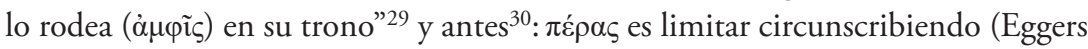

\footnotetext{
24 "Instead of a vague periphrastic and unnecessary abstractions, it presents the concrete, a graphic image" (Onians, 1951: 324).

${ }^{25}$ Homero, Iliada, XXI, 194.

${ }^{26}$ Hesíodo, Obras y Fragmentos, IV, 8.

${ }^{27}$ Homero, Iliada, XVIII, 490.

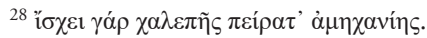

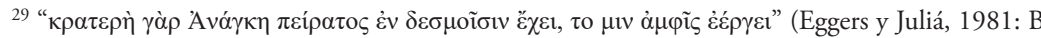
$8,30)$.

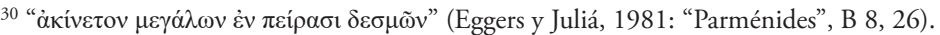


y Juliá, 1981: "Parménides", B 8, 26-30). ${ }^{31}$ Ya en el siglo XX, H. G. Gadamer

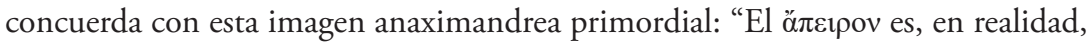
aquello que, al girar siempre sobre sí mismo como un anillo, no tiene inicio ni final. Es la maravilla el ser: el movimiento que se regula a sí mismo continuamente y prosigue hacia el infinito [...] Heidegger observó justamente este punto decisivo" (Gadamer, 1999: 104-105).

Independientemente de las reflexiones de Heidegger sobre Anaximandro — de las cuales he hablado en otro lugar (López Espinoza, 2014) —, las fuentes poéticas

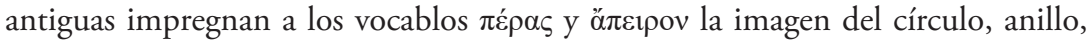
envoltura o circunferencia espacialmente determinada. ¿Anaximandro utiliza ö̈rદıрov en el mismo sentido? Ya el hecho de usarlo dice bastante. Como todo griego antiguo está familiarizado desde su nacimiento con los mitos transmitidos por sus compatriotas poetas, particularmente Homero, Hesíodo y posteriormente Esquilo. Resulta complicado pensar en un Anaximandro sin conocimiento del manejo poético del término, dudoso presentarlo totalmente ajeno a las costumbres de su pueblo. Hermann Diels, por ejemplo, mientras concibe su magna obra de los

${ }^{31}$ Bajo un esquema semejante podemos comprender la significación poética de ö́rદipov. En Odisea

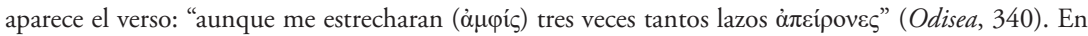

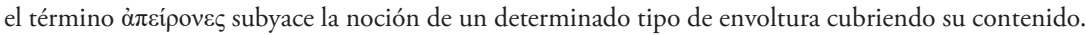
Análogamente, cuando Ulises canta su arribo a la isla de Ea, hogar de Circe (2013), describe la superficie

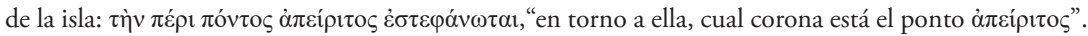
Encontramos aquí la primera referencia directa donde se vinculan la circunferencia de Océano, $\pi \varepsilon ́ p$

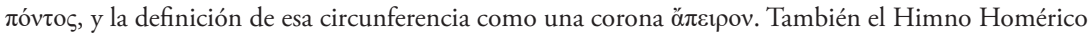
a Apolo menciona una concepción afín: el redondeado golfo de Crisa, al sur del Peloponeso, es llamado

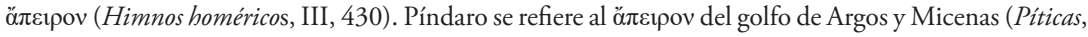
IV, 47). En Teogonía, Hesíodo relata la funesta lucha entre los Titanes y los dioses Olímpicos. La rudeza del enfrentamiento hacía retumbar al Océano mismo: "Y mugía horriblemente el ponto ả $z \varepsilon i ́ p \omega v "$ (Teogonía, 679). Con el verbo $\pi \varepsilon \rho u \alpha ́ \alpha \omega$, la imagen plasmada por el aedo tesalio es la del mar äjzipov haciendo un tremebundo ruido a su alrededor. Para la época de Anaximandro — bien lo nota el propio Cornford (Cornford, 1987: 212-213)—, los poetas griegos perpetúan el juicio y la relación entre ö̈rєıov y la circunferencia. Principalmente los trágicos se inclinan por esta apreciación. En Esquilo (Agamenón,

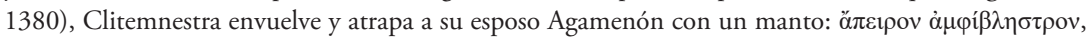
con una clase de red que cerca y acorrala a los peces. Eurípides, siguendo a Esquilo, expresa: "después

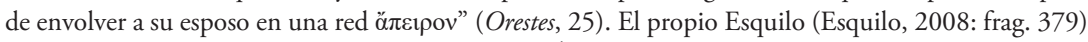
describe el gesto de las mujeres frente al altar de Ártemis: "una cinta ö́દıрov", llamándole así a la disposición circular de las devotas. Eurípides (Eurípides, 2002: frag. 208) nombra ö en la cosmovisión homérica, el éter, porque es redondo y cerca con sus extremidades a Gea, la Tierra, y además señala que Uranos, el cielo, es ö́zєıрov, pues circunda la Tierra con húmedos brazos. Finalmente, Aristófanes (Aristófanes, 2009: frag. 250) compone el siguiente verso: "llevando un anillo ä $\pi \varepsilon t \rho o v ~ d e$ bronce", refiriéndose, evidentemente, a la forma circular del anillo. En la Física (Física, 207a2), el propio Aristóteles es conciente de esta terminología poética cuando asegura que los anillos, las sortijas, son

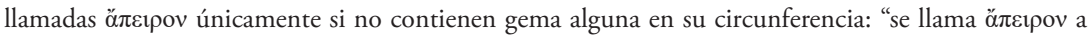
esos anillos que carecen de engarce". 


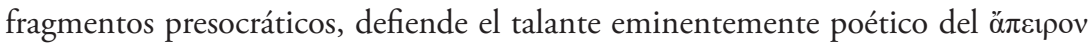
anaximandreo, le nombra un Urpoetisher Gedanke, "pensamiento poético-originario” (Diels, 1897: 235). En tanto Urpoetisher Gedanke, lo äjeipov dificilmente puede reducirse a una superfice o la representación mental de la circunferencia. Cuando Anaximandro mienta ö́rєıрov, el contenido mítico-poético de la palabra le ayuda a expresar algo surgido o vinculado a la imagen tradicional propagada en la poesía, y esa imagen arcaica del círculo, trasluce una experiencia vital conectada hondamente con la mitología. Podríamos, en efecto, siguiendo el citado pasaje de Gadamer, intepretar ontológicamente la circularidad de öreıрov notando en éste un movimiento, un giro sin principio ni final capaz de alumbrar "la maravilla del ser”. Mas ese giro circular permanente también puede expresarse, y de hecho se ha expresado originariamente, a través de otras vías con igual o mayor efectividad al análisis ontológico. El mito del rapto de Perséfone, su estancia en el Inframundo y su retorno, anida en sí mismo esa potencialidad dadora de sentido.

Dentro del marco mitológico de los misterios eleusinos, el alojamento de Perséfone en el Hades marca un punto culminante en la narración. Tras el rapto, la muchacha habita en el lobrego paraje submundando para transformarse en consorte del dios, "Señora del Hades”. De acuerdo con Karl Kerényi, la figura de Пótvi $\alpha$, "Señora" del Inframundo, es mitológicamente consustancial a otro epíteto, "Señora del laberinto": la "Señora del Inframundo", Perséfone, es "Señora del laberinto" (Kerényi, 1998: 82). ${ }^{32}$ ¿Qué quiere decir esta analogía? Detengámonos brevemente en ello. Al excavar las ruinas del santuario de Apolo en Dídima, Mileto — patria de Anaximandro-, el arqueólogo Theodor Wiegand descubre una doble escalera en forma de caracol construida a la entrada del templo apolíneo. La escalera espiral llega al techo del templo. En su ascensión, cada estrato está decorado, a la par de la escalinata, por figuras de meandros y espirales, identificados en varias ocasiones con inscripciones que le definen como $\lambda \alpha \beta v$ pıv $\theta$ os, "laberinto". ${ }^{33}$ Demostrado por diversos estudios arqueológicos — numismática, epigrafía, etcétera- para las civilizaciones antiguas el laberinto se plasma a través de imágenes circulares, meandros o espirales (Kerényi, 2006: 51). Todavía en el Medioevo se llama labyrinthus al meander. En la antigua Grecia, las iconografías en forma de meandros, siempre variadas, aparecen pintadas o gravadas en múltiples basamentos (en Knosos, Festo,

32 "En Ariadna no sólo se reflejaban grandes diosas, como Artemisa, Afrodita y Perséfone... ella era Perséfone y Afrodita en una persona" (Kerényi, 1998: 84). Por su protagonismo en el mito de Teseo y el Minotauro, la arqueología considera que los vestigios atribuidos a la "Señora del laberinto" se refieren a Ariadna, a quien, según Ilíada, Dédalo acondiciona una danza conocida por los especialistas como "danza del laberinto" (Ilíada, XVIII, 590). Véase Lawler (1945: 62).

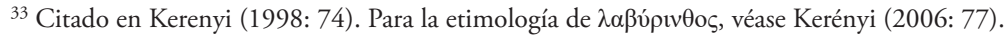


Tirinto, Micénas, Orcómeno, las Cícladas, etcétera) y en ofrendas votivas, ánforas, cráteras y otros utensilios regados a lo largo y ancho del territorio heleno (Kerényi, 2006). En la literatura clásica, por ejemplo, el propio Platón conoce esta forma popular cuando hace decir a Sócrates: "como si hubiésemos caído en un laberinto (

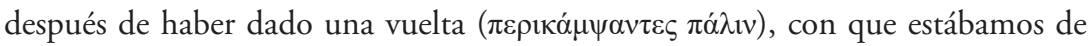
nuevo en el punto de partida” (Eutidemo, 291b). La figura plana en espiral, impresa en la iconografía antigua, trasluce la forma de un espacio circular donde comienzo y final se pierden. Los dialogantes Sócrates y Clinias, atrapados por el $\lambda \alpha \beta u ́ p \imath v \theta \_$ de elencos sofísticos, creyendo encontrar la salida, retornan al principio.

Heródoto describe el laberinto egipcio en Hawara, una de las siete maravillas de la Antigüedad, como edificación inigualable, dividida en una sección subterrá-

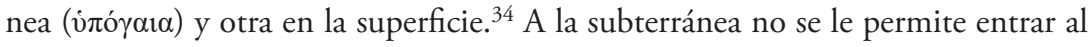
historiador debido al carácter sagrado atribuido por los guías egipcios, pues hay faraones enterrados; la superficial, por su parte, está constituida de múltiples cámaras engarzadas por un "intrincado dédalo de pasadizos", 35 lo cual hace suponer que las estancias subterráneas poseen las mismas redondeadas características. En su Nekia, Virgilio ${ }^{36}$ narra cómo Eneas, al arribar a Cumas, relaciona el laberinto dedálico con una puerta al Inframundo. Para el mismo Platón, el Inframundo está

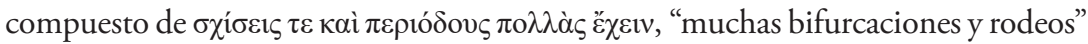
(Fedón, 108a). ${ }^{37}$ Cuando Kerényi titula su estudio "El laberinto como reflejo lineal de una idea mitológica", sugiere que los círculos y espirales descubiertos por la arqueología moderna refractan, en última instancia, esa "idea mitológica”, Mythologischen Idee, iluminada a través del Inframundo griego y, por ende, evidencian la reveladora interconexión de los epítetos de la diosa eleusina: Perséfone es señora del Hades y del Laberinto, su espejo visible (Kerényi, 2006: 166).

Viviendo en el Hades, en el Laberinto, Perséfone posee sin duda un eminente carácter mortuorio. En cuanto idea mitológica, empero, no es únicamente la idea de la muerte sin más. La "Señora del Laberinto" señala una trans-formación, un continuum: vida con su madre Deméter, rapto, descenso, estancia en el Inframundo y, finalmente, retorno de la muerte. Cornford, recordemos, observa con suma nitidez la "Idea" experimentada en Eleusis: el continuo fluir de todo lo vivo en el movimiento vida-muerte-vida-muerte. Esa ida y vuelta, ese comienzo acoplado con

\footnotetext{
${ }^{34}$ Heródoto, Historia, 148.

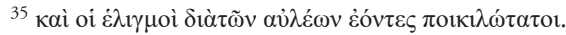

${ }^{36}$ Virgilio, Eneida, VI, 14.

${ }^{37}$ Tpıódous [ Dobree/Proclo ].
} 
el fin, ese movimiento radical y total, el pueblo heleno también lo celebra con danzas circulares al interior del santuario eleusino; la palingenesia del iniciado, su muerte y renacimiento, es al mismo tiempo una danza festiva. Desafortunadamente no podemos detenernos en este aspecto en verdad importante de la experiencia eleusina y su horizonte mistérico. Sirvan las siguientes coplas de Eurípides para atisbar su profundo simbolismo: "si junto a las fuentes rodeadas de hermosos coros llega a ver como espectador en la noche y despierto las antorchas el día veinte, cuando hasta el éter estrellado de Zeus se revuelve danzando y danza la luna y las cincuenta hijas de Nereo, que en el ponto y en las corrientes de los ríos de perpetua corriente danzan por la Virgen de la corona de oro y su venerable Madre [i. e. Perséfone y Deméter]" (Ion, 1075). ${ }^{38}$ En Eleusis, pues, acontece un baile circular iniciático alrededor de una fuente, quienes participan en la ceremonia portan en sus sienes la figura de la corona, imitando a la "dorada corona" de Perséfone. ${ }^{39} \mathrm{El}$ citado fragmento de Esquilo, por ejemplo, nombra precisamente ö $\varepsilon \varepsilon 1 \rho \circ v$ a la disposición de los bailes femeninos alrederor de otro templo, el de Artemis. ${ }^{40}$

$\mathrm{Al}$ respecto de esta última referencia a ójectpov, resulta por demás extraordinario el comentario de Simplicio cuando se refiere a las distintas acepciones del término aparecidas en la Física de Aristóteles. ${ }^{41}$ El doxógrafo desarrolla al menos cinco significados. Entre éstos, enuncia los más usuales para los peripatéticos e incluye, en su cuarta definición, la noción de circularidad ejemplificada con Océano ö́rııov rodeando la Tierra. La tercera connotación es la más asombrosa. Dice literalmente

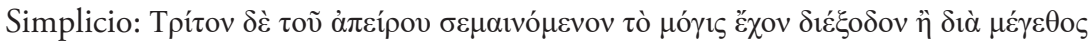

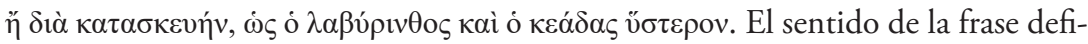

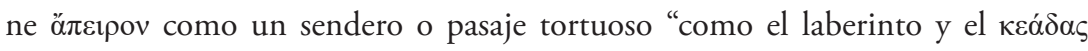

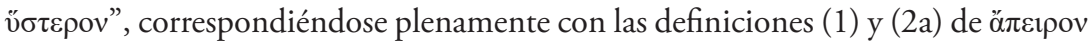
hechas por Aristóteles en la Física (Física, III, 204a); definiciones, por cierto, que dan cuenta del significado más arcaico de ö́rєıрov. ${ }^{42}$ De entrada, si para Simplicio

${ }^{38}$ Las ruinas excavadas en el templo de Eleusis evidencian la presencia, en época arcaica y mucho antes, de una plancha destinada a un baile ceremonial preparatorio. Los iniciados danzarían alrededor de una fuente o pozo llamado Kallichoron, "de las bellas danzas" o "del bello coro", cuya estructura está constituida por un amplio basamento circular. Cuando, según Heródoto (Historia, IX, 65), los persas atacan Salamina en el siglo V a. C. (circa 480), prenden fuego al santuario eleusino. El interior del santuario es reconstruido después, erigiendo un muro que rodea el templo de las diosas, arruinando por completo el terreno para danzar (Kerényi, 2004: 38, 48, 61).

${ }^{39}$ Aristófanes, Nubes, 250; Bat. 325.

${ }^{40}$ Sobre la danza circular en honor a Artemis, veáse Calímaco, Himnos y epigramas, 267.

${ }^{41}$ Simplicii in Aristotelis Physicorum libros quattuor priores commentaria, III, 4.

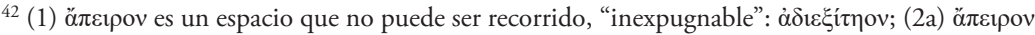

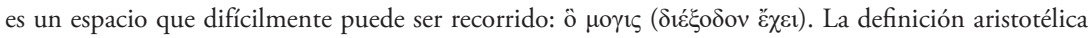


uno de los significados de ö́zєıрov es "laberinto" confirma, a todas luces, la unión con la imagen mitológica circular transmitida por los poetas griegos y por la iconografía antigua. Al mentar ö́zєıрov, se mienta, en su sentido mítico-poético ori-

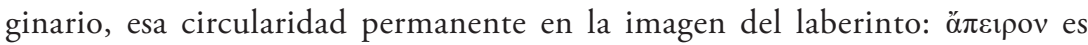
$\lambda \alpha \beta u ́ p ı v \theta o s ;$ plástica imagen del Inframundo. Pero el asunto no termina aquí. A la

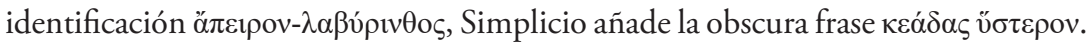
De acuerdo con Pierre Chantraine, el vocablo $\kappa \varepsilon \alpha ́ \delta \alpha \varsigma$ está emparentado con el védico kevala, "fosa" o con kai-wr/n-i, "caverna", siendo posible interpretar a su vez

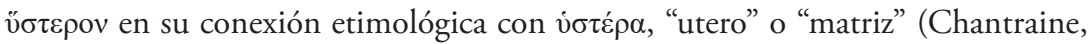

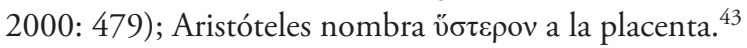

Con tales consideraciones, Simplicio ilustra el término ö $\pi \varepsilon \imath \rho o v$, primero, con la imagen del laberinto, y segundo, con una caverna o fosa semejante a un útero, $\kappa \varepsilon \alpha ́ \delta \alpha \varsigma$ v̋ $\tau \varepsilon \rho o v$. La figura de la placenta, en su aspecto de emboltura, encaja sin problema con la imagen poética de ö́єєıрov, pero además, las mútiples y rebuscadas dendritas de esta fuente orgánica son análogas a las figuras meándricas arboresentes bien presentes en la iconografía laberíntica. El propio Simplicio nos da más pistas

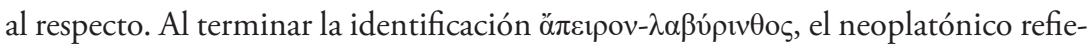
re tangencialmente a la narración del rey Aristómenes de Mesenia, diciendo tan sólo: "a quien el zorro alumbra el pasadizo". ${ }^{44}$ Pausanias narra la historia de Aris-

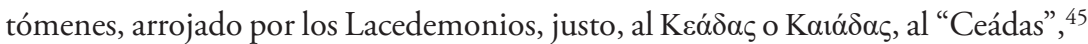
una grieta, fosa o caverna espartana en la cual son lanzados los criminales. ${ }^{46}$ Por gracia divina, Aristómenes no muere dentro de la cueva. Al tercer día, en la oscuridad, escucha ruidos, se percata que un zorro está comiendo los cadáveres putrefactos. El mesenio se las ingenia para seguir al zorro y encontrar la salida. Una vez fuera, lo encuentran los Lacedemonios. El acontecimiento parece tan increíble a los espartanos: "como si se hubiera dicho que un muerto habría resucitado". ${ }^{47}$

En sintonía con la tradición mítico-poética griega - y con la definición aristotélica- para Simplicio ö́rєıрov es un laberinto, una cueva en forma de útero redon-

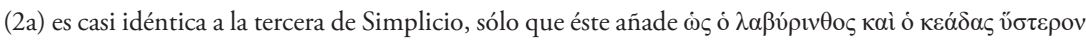
para esclarecer el sentido. Solmsen considera que la combinación de las definiciones (1) y (2a) del Estagirita muestran la concepción más arcaica de ä́દıрov (Solmsen, 1962: 122-123). Según Solmsen,

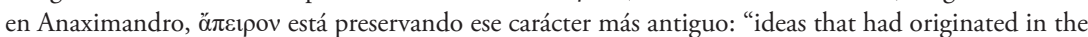
imagination of poets". Las referencias de Aristóteles y Simplicio sólo transmiten ese significado primigenio de öreıрov.

${ }^{43}$ Aristóteles, Investigación sobre los animales, $587 \mathrm{a} 8$.

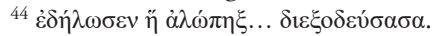

${ }^{45}$ Pausanias, Descripción de Grecia, IV, 18, 4.

${ }^{46}$ Tucídides, Historia de la guerra del Peloponeso, I, 134, 4.

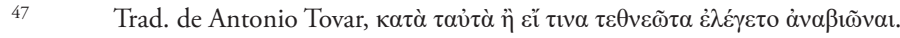


deada, de donde un ser humano, por fortuna divina, es devuelto a la vida; renace de la muerte. Esto tiene en mente el comentador, su mención de Aristómenes y el zorro lo demuestra. Debería existir un aire familiar en la narración de Pausanias para que Simplicio identificase al laberinto, al Ceádas subterráneo y ö́rєıюv. Quizá porque la propia tradición ya lo había hecho. No parece casual la narración inmediatamente posterior escrita por Pausanias: una vez renacido de entre los cadáveres, salido del laberinto-caverna, Aristómenes es emboscado en una finca por los espar-

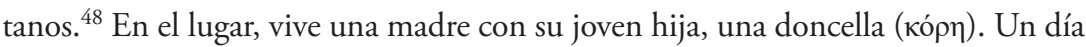

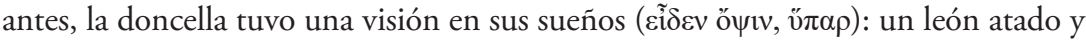
sin uñas era llevado a la finca por lobos; ella liberaba al león. Cuando la chica vio entrar a Aristómenes, supo qué debía hacer. Esperó a la noche y liberó al mesenio.

La anécdota de Pausanias muestra míticamente la conexión profunda entre caverna, muerte, renacimiento y cómo ese movimiento cíclico de regeneración, los helenos irremediablemente le atribuyen una presencia eleusina. Para griegos como Pausanias, en la "Idea" del ciclo vital, renacimiento de todo lo vivo, siempre acechan la madre y su hija con "aurea corona”. El laberinto sería la imagen originaria de esa serpenteante caverna uterina a partir de la cual los seres vivos se alzan hacia la luz para descender nuevamente a sus entrañas: äjeıрov. Aquella noción ontológicamene elaborada por Gadamer, el movimiento anular, ö́zєıрov, capaz de alumbrar la "maravilla del ser", puede expresarse, en términos de Cornford, cual "Idea" de la palingenesis iniciática en Eleusis. El Urpoestischer Gedanke, connatural a poetas como Schiller o Goethe, según el propio Diels, es ese öreıрov mítico renuente a ser vislumbrado por la mirada moderna, tan ocupada por distanciarse del mito. Un filósofo belga estudioso de la Antigüedad, Marcel De Corte, hablando de los cruces

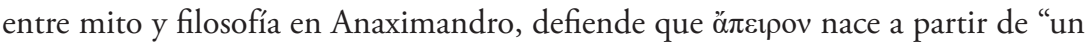
símbolo... una imagén mítica, una intución metafísica (image mythique une intution métaphysique)", proyectando un cosmos "reconstruido cual obra de arte y penetrada por valores religiosos" (De Corte, 1959: 13, 28-29). Intuición metafísica, de acuerdo con el mismo autor, semejante a lo revelado en "las figuras arcaicas de la Madre-Tierra, Deméter y Core" (1959). En su poco conocida obra Philosophie und Religion, también Schelling comparte esta visión al defender la primitiva hermandad entre los antiguos misterios y los primeros filósofos griegos; los primeros filósofos son los "promotores de los misterios" (Urheber der Mysterien), según el propio Schelling, conectados con la experiencia eleusina (Schelling, 2010: 7, 27). Pero, más aún, Aristóteles y con mayor transparencia Simplicio, tienen presente que a la par de la intepretación "física" de ö́rєıрov, desarrollada y mejor conocida

\footnotetext{
${ }^{48}$ Pausanias, Descripción..., IV, 19, 4.
} 
por ellos, existe un sentido arcaico inapresable con las categorías del pensamiento peripatético; sentido que sus ancestros experimentaron mejor a través de la mitología. Al pintar en sus templos grabados espirales y meandros, los griegos recordaban lo vivido en la fiesta eleusina; mientras bailaban en círculos en honor a la diosa, recordaban la relevancia de llevar una vida distinta, donde la muerte está

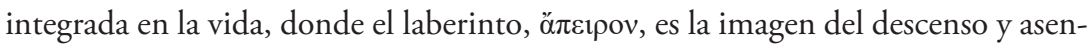
so de todo lo vivo: "El hecho de que todo lo que nace tenga que morir no es un destino adverso dado por una potencia. La muerte está ya activamente presente en el propio nacimiento, en el acto mismo de la generación: es la condición previa para el surgimiento de una nueva vida [...] Ésta es, pues, la idea fundamental del mito de Perséfone" (Otto, 2004: 54). 


\section{Bibliografía}

Aragay, Narcís. (1993). Origen y decadencia del logos. Giorgio Colli y la afirmación del pensamiento trágico. Barcelona: Anthropos.

Aristófanes. (2006). Las nubes, Las Ranas (Francisco Rodríguez, Trad.). Madrid: Cátedra.

Aristófanes. (2008). Fragments (Jeffrey Henderson, Trad.). Londres: Loeb.

Aristóteles. (1992). Investigación sobre los animales (Julio Pallí, Trad.). Madrid: Gredos.

Aristóteles. (1995). Física (Guillermo R. de Echandía, Trad.). Madrid: Gredos. Aristóteles. (1996). Acerca del cielo - Meteorológicos (Miguel Candel, Trad.). Madrid: Gredos.

Aujac, Germaine. (1984). La geografia nel mondo antico. Napoli: Edizioni Scientifiche.

Burnet, John. (1994). La aurora de la filosofía griega (O. Muñoz, Trad.). México: Argos.

Calímaco. (1984). Himnos y epigramas (Pedro Tapia Zuñiga, Trad.). México: unam.

Chantraine, Pierre. (2000). Dictionnaire étymologique de la langue grecque. Paris: Klincksieck.

Cherniss, Harold. (1991). La crítica aristotélica a la filosofía presocrática (Conrado Eggers, Trad.). México: unam.

Colli, Giorgio. (1996). Filosofía de la expresión (Miguel Morey, Trad.). Madrid: Siruela.

Colli, Giorgio. (2008). La sabiduría griega II (Dionisio Mínguez, Trad.). Madrid: Trotta.

Cornford, Francis M. (1981). Antes y después de Sócrates (Antonio Pérez-Ramos, Trad.). Barcelona: Ariel.

Cornford, Francis M. (1987). Principium sapientiae. Los origenes del pensamiento filosófico griego (Rafael Guardiola, Trad.). Madrid: Visor.

Couprie, Dirk L. (2002). “The Discovery of Space: Anaximander Astronomy”. En Dirk L. Couprie, Roberth Hahn y Gerard Naddaf, Anaximader in context (pp. 167-236). Albany: suny Press.

De Corte, Marcel. (1959). "Mythe et philosophie chez Anaximandre". Laval théologique et philosophie, 14(1), 9-29. doi: https://doi.org/10.7202/1019959ar

Dicks, David R. (1955). “The KAIMATA in Greek Geography”. The Classical Quarterly, 5(3-4), 248-255. doi: https://doi.org/10.1017/S0009838800011538 
Dicks, David. R. (1959). “Thales”. The Classical Quarterly, 9(3-4), 294-309. doi: https://doi.org/10.1017/S0009838800041586

Dicks, David R. (1966). "Solstices, equinoxes, and the presocratics". The Journal of Hellenic Studies, 86, 26-40. doi: https://doi.org/10.2307/628990

Dicks, David R. (1970). Early Greek Astronomy to Aristotle. New York: Cornell University Press; Ithaca.

Dicks, David R. (1972). "More Astronomical Misconceptions". The Journal of Hellenistic studies, 92, 175-177. doi: https://doi.org/10.2307/629984

Diels, Hermann A. (1897). "Über Anaximander Kosmos”. Archiv Für Geschichte der Philosophie, (10).

Diógenes Laercio. (2007). Vidas y opiniones de los filósofos ilustres (Carlos García Gual, Trad.). Madrid: Alianza.

EgGers Lan, Conrado; y Juliá, Victoria E. (1981). Los filósofos presocráticos I. Madrid: Gredos.

Esquilo. (1980). Tragedias (Bernardo Perea Morales, Trad.). Madrid: Gredos.

Esquilo. (2008). Fragmentos - Testimonios (Carlos García Gual, Trad.). Madrid: Gredos.

Estrabón. (2002). Geografía (IV Tomos) (J. L. García). Madrid: Gredos.

Euripide. (2002). Fragments (François Jouan y Herman van Looy, Trads.). Paris: Les Belles Lettres.

Eurípides. (1985). Tragedias II (José Luis Calvo Martínez, Trad.). Madrid: Gredos. Eurípides. (1998). Tragedias III (Carlos García Gual, Trad.). Madrid: Gredos.

Eusebio de Cesárea. (2011). Preparación Evangélica (Jesús María Nieto, Trad.). Madrid: BAC.

Flavio Josefo. (1994). Autobiografía. Contra Apión (Margarita Rodríguez, Trad.). Madrid: Gredos.

Furley, David. (1987). The Greek Cosmologists. Cambridge: University Press.

Gadamer, G. Hans. (1999). El inicio de la filosofía occidental (Joan Mussarra, Trad.). Barcelona: Paidos.

Graham, Daniel. (2006). Explaining the Cosmos. The Ionian Tradition of Scientific Philosophy. Princeton: Princeton University Press.

Graham, Daniel. (2013). Science Before Socrates: Parmenides, Anaxagoras, and the New Astronomy. Oxford: Oxford University Press.

Graham, Daniel. (2013). Science before Socrates. Oxford: Oxford University Press. Guthrie, W. K. (1970). “Aristotle as Historian”. En David Furley y Reginald Allen, Studies in Presocratic Philosopy I (pp. 239-254). New York: Humanities Press. Hahn, Robert. (2001). Anaximander and the Architects. New York: sunY. 
Heródoto. (2001). Historia (VTomos) (Carlos Schrader, Trad.). Madrid: Gredos. Hesíodo. (1978). Obras y Fragmentos: Teogonia, Trabajos y Dias, Escudo, Fragmentos, Certamen (Aurelio Péres Jiménez y Alfonso Martínez Diez, Trad.). Madrid: Gredos.

Hesíodo. (2016). Teogonía (Paola Vianello, Trad.). México: unam; Coordinación de Humanidades; Instituto de Investigaciones Filológicas.

HIMNOS HOMÉRICOS - La "Batracomiomaquia". (1978). (Alberto Bernabé Pajares, Trad.). Madrid: Gredos.

Homero. (2010). Ilíada (Emilio Crespo Güemes, Trad.). Madrid: Gredos.

Homero. (2013). Odisea (Pedro C. Tapia Zúñiga, Trad.). México: Programa Editorial de la Coordinación de Humanidades.

Jámblico. (2003). Vida Pitagórica - Protréptico (Miguel Periago Lorente, Trad.). Madrid: Gredos.

Jones, Alexander. (1991). "The Adaptation of Babylonian Methods in Greek Numerical Astronomy”. History of Science Society, 82(3), 440-453. doi: https:// doi.org/10.1086/355836

KaHn, Charles. (1970). "On Early Greek Astronomy”. The Journal of Hellenistic studies, 90, 99-116. doi: https://doi.org/10.2307/629756

KaHn, Charles. (1994). Anaximander and the Origins of Greek Cosmology. Cambridge: Hackett.

KerénYI, Károly. (1998). Dionisios. Raiz de la vida indestructible. (Adan Kovacksics, Trad.). Barcelona: Herder.

Kerényi, Károly. (2004). Eleusis (María Tabuyo, Trad.). Madrid: Siruela.

KerénYi, Károly. (2006). En el laberinto (B. Keimann, Trad.). Madrid: Siruela.

Kirk, Geoffrey S.; Raven, John E.; y Schofield, M. (1977). Los filósofos presocráticos (I-III) (Jesús García Fernández, Trad.). Madrid: Gredos.

LaWler, Lilian B. (1945). “ $\Delta \imath \pi \lambda \tilde{\eta}, \delta \imath \pi \circ \delta i \alpha, \delta \imath \pi o \delta ı \sigma \mu o ́ s$ in the Greek Dance”. Transactions of the American Philological Association, 76, 59-73.

LIRICA GRIEGA ARCAICA. (1959). (Francisco Rodríguez Adrados, Trad.). Barcelona: Alma Mater.

López Espinoza, Marco A. (2014). "Sobre el origen de la filosofía: Anaximandro desde Heidegger”. Reflexiones Marginales, 22.

López Espinoza, Marco A. (2019). Jenófanes y los dioses griegos. Poesía y filosofía en época arcaica. México: UnAM; Monosílabo.

Mansfeld, Jaap. (2010). "Bothering the Infinite. Anaximander in the Nineteenth Century and Beyond”. Antiquorum Philosophia. An international journal, 3, 9-68. doi: http://digital.casalini.it/10.1400/127749 
Mansfeld, Jaap; y Runia, David. (2009). Aëtiana: The method and intellectual context of a doxographer II. Leiden: Brill.

McDiarmid, J. B. (1953). "Theophrastus on the Presocratic Causes". Harvard Studies in Classical Philology, (61), 85-156. doi: http://doi.org/10.2307/310774

NaddaF, Gerard. (2002). "Anthopogony and Politogony in Anaximander of Miletus". En Dirk L. Couprie, Roberth Hahn y Gerard Naddaf, Anaximader in context (pp. 9-71). Albany: suny Press.

Neugebautr, Otto. (1972). “On Some Aspects of Early Greek Astronomy”. Proceedings of the American Philosophical Society, 116(3), 243-251.

Neugebauer, Otto. (1975). A history of Ancient Mathematical Astronomy. Berlin: Springer; Verlag.

Nietzsche, Friedrich. (2003). Los filósofos preplatónicos (Francesc Ballesteros, Trad.) Madrid: Trotta.

Onians, Richard B. (1951). The Origins of European Thought. Cambridge: Cambridge University Press.

Отто, Walter. (2004). "El sentido de los misterios eleusinos”. En C. G. Jung, W. F. Otto, H. Zimmer, P. Hadot y J. Layard, Hombre y Sentido. Círculo Eranos III (Luis Garagalza, Trad.) (pp. 46-68). Madrid-México: Anthropos; unAM.

Pausanias. (1994). Descripación de Grecia (María Cruz Herrero, Trad.). Madrid: Gredos.

PÉDech, Paul. (1976). La géographie des grecs. Vendôme: Presses Universitaires de France.

Píndaro. (1984). Odas y Fragmentos (Alfonso Ortega, Trad.). Madrid: Gredos.

Platón. (1988). Diálogos III. Fedón. Banquete. Fedro (Carlos García Gual, Trad.). Madrid: Gredos.

Platón. (2010). Diálogos II. Gorgias. Menéxeno. Eutidemo. Menón, Crátilo (J. L. Calvo, E. Acosta Méndez, E. J. Olivieri y J. Calonge Ruiz, Trads.). Madrid: Gredos.

Plutarco. (1995). Obras morales y de costumbres (Moralia) IV (Francisca Pordomino y José Antonio Fernández, Trads.). Madrid: Gredos.

Proclus. (1992). A Commentary on the First Book of Euclid's Elements (Glenn R. Morrow, Trad.). Princeton: Princeton University Press.

Rossetti, Livio. (2015). "El tratado peri physeos de Anaximandro". Nouva Tellus: Anuario del Centro de Estudios Clásicos, (32-2), 57-73.

Rovelli, Carlo. (2011). Anaximander (Marion Lignana, Trad.). Yardley: Wetholme. Schelling, Friedrich W. J. (2010). Philosophy and Religion (Klaus Ottman, Trad.). Connecticut: Spring. 
SIMPLICII IN ARISTOTELIS Physicorum libros quattuor priores commentaria (Herman Diels, Ed.). (2012). Berlin: De Gruyter.

Solmsen, Friedrich. (1962). "Anaximander's Infinite: Traces and influences”. Archiv Für Geschichte der Philosophie, 44(2), 109-131.

Stokes, Michael. (1971). One and the Many in Presocratic Philosophy. Cambridge: Harvard University Press.

Tucídides. (2000). Historia de la guerra del Peloponeso (Juan José Torres, Trad.). Madrid: Gredos.

Vernant, Jean-Pierre. (1973). Mito y pensamiento en la Grecia Antigua (Juan Diego López, Trad.). Barcelona: Ariel.

Vernant, Jean-Pierre. (1992). Los orígenes del pensamiento griego (Marino Ayerra, Trad.) Barcelona: Paidos.

Virgilio. (1992). Eneida (Vicente Cristóbal, Trad.). Madrid: Gredos.

West, Martin L. (1996). Hesiod, Theogony. Oxford: Oxford University Press.

White, Stephen. (2002). "Thales and the Stars". En Daniel W. Graham, Victor M. Caston y Alexander P. D. Mourelatos, Presocratic Philosophy. Essays in Honour of Alexander Mourelatos (pp. 3-18). New York: Routledge. 